\title{
Tingkat, Klasifikasi Dan Tipe Keputusan
}

\author{
Lia Ariska Ritonga \\ Universitas Islam Negeri Sumatera Utara Medan
}

Corresponding Author : Liaariskaritonga30@gmail.com

\begin{tabular}{ll}
\hline \multicolumn{1}{c}{ ABSTRACT } \\
\cline { 2 - 3 } & \multicolumn{1}{c}{$\begin{array}{c}\text { Keputusan strategis merupakan penentu arah tindakan organisasi dimasa } \\
\text { mendatang. Bentuk dari keputusan strategis sangat berorientasi pada } \\
\text { masa depan organisasi. Salah satu bentuk keputusan strategis misalnya } \\
\text { menentukan produk, menentukan lokasi perusahaan dan menentukan } \\
\text { diferensiasi produk. Sedangkan partisipasi dalam pengambilan } \\
\text { keputusan yang dimaksud adalah pengambilan keputusan yang } \\
\text { dilakukan oleh anggota yang tergabung dalam kelompok yang disebut } \\
\text { dengan pengmbilang keputusaan kelompok. Dalam menetapkan dan } \\
\text { meningkatkan mutu, apakah keputusan yang diambil secara individual } \\
\text { atau oleh partisipasi kelompok yang lebih efektif dan memuaskan orang- } \\
\text { orang yang terlibat dalam suatu lembaga }\end{array}$} \\
\cline { 2 - 3 } Kata Kunci & Klasifikasi, Tipe Keputusan \\
\cline { 2 - 3 } How to cite & (2021). Jurnal Ability, 2(3). \\
\cline { 2 - 3 } &
\end{tabular}

\section{PENDAHULUAN}

Mengambil atau membuat keputusan adalah kondisi dalam pilihan, biasanya dalam membuat keputusan akan banyak berbagai alternatif te tapi pembuat keputusan harus memilih salah satu alternatif dari sekian banyak alternatif karena dalam membuat atau mengambil keputusan itu berkaitan dengan menentukan keputusan mana, dari sekelompok alternatif yang mungkin dan yang optimal untuk suatu kondisi tertentu. Dalam proses membuat keputusan salah satu komponen yang penting adalah mengumpulkan banyak informasi.

Berdasarkan kajian metode, keputusan terpecah menjadi empat, yaitu, metode keputusan rasional, metode keputusan tawar menawar, metode keputusan agregatif, dan metode keputusan keranjang sampah. Sehubungan dengan pendekatan metode berbagai aliran pun dapat sesuai untuk mengkaji keputusan. Aliran-aliran yang dimaksudkan adalah birokratik, manajemen saintifik, hubungan kemanusiaan, rasionalitas ekonomi, kepuasan dan analisis sistem. 
Ability : Journal of Education and Social Analysis

Volume 2, Issue 3, Juli 2021

Page : 65-69

\section{METODOLOGI PENELITIAN}

Penelitian ini menggunakan studi kepustakaan (library research). Dalam memperoleh data penelitian, peneliti mengumpulkan, menganalisis, mengorganisasi, sumber dari artikel, buku, penelitian terdahulu tentang implementasi manajemen strategi dalam bidang pendidikan. Kemudian peneliti menyimpulkan dan menyajikan data-data manajemen strategi untuk peningkatan mutu pendidikan (Danandjaja, 2014; Sari \& Asmendri, 2020; Zed, 2014).

\section{HASIL PENELITIAN DAN PEMBAHASAN}

A. Tingkatan Managemen

Dalam pengambilan keputusan sangat bergantung pada tingkatan managemen, yang mana managemen itu sendiri memiliki tiga tingkatan, diantaranya adalah sebagai berikut :

1. Managemen Lini Pertama

Managemen lini pertama merupakan tingkatan managemen yang paling bawah dalam sebuah organisasi. Manajemen lini pertama ataulow Level Management adalah tingkatan manajemen yang berada paling rendah dalam suatu organisasi perusahaan. Tugas mereka adalah memimpin dan mengawasi performa tenaga kerja operasional. Oleh karena itu, manajemen tingkat pertama ini akan lebih mengandalkan kemampuan teknikal dan kemampuan komunikasinya.

Berbagai kemampuan dalam hal konseptual hampir tidak dibutuhkan sama sekali oleh manajer lini pertama. Selain itu, mereka juga tidak membawahi manajer lainnya. Contoh sebutan yang berlaku untuk manajemen tingkat pertama ini adalah supervisor atau mandor. Mereka secara langsung dipilih oleh manajemen tingkat menengah. Selain itu, mereka juga menjadi bagian dari manajemen operasional yang terlibat langsung dalam seluruh proses produksi dan bertanggung jawab untuk bisa menyelesaikan berbagai rencana dan tugas yang telah diberikan oleh manajemen tingkat menengah.

2. Managemen Tingkat Menengah

Manajemen tingkat menengah memiliki posisi tengah dari hirarki manajemen pada suatu perusahaan. Manajemen menengah ditunjuk langsung oleh manajemen puncak. Tugas dang tanggung jawabnya pun sudah ditentukan oleh manajemen puncak.Mereka yang berada pada tingkat manajemen tengah akan cenderung bekerja dengan mengandalkan kemampuan manajerial dan berbagai hal teknis lainnya. Jadi, mereka tidak terlalu membutuhkan kemampuan yang sifatnya lebih konseptual. 
Ability : Journal of Education and Social Analysis

Volume 2, Issue 3, Juli 2021

Page : 65-69

Manajemen tingkat menengah juga akan memimpin dan mengarahkan seluruh kegiatan manajer yang ada dibawahnya. Mereka akan bertanggung jawab pada seluruh kegiatan yang dilakukan oleh tingkat menajemen yang lebih rendah, dan bahkan kerap kali bertanggung jawab pada beberapa karyawan operasional. Beberapa contoh sebutan tingkat manajemen tengah adalah kepala departemen atau HOD, manajer cabang, junior executive, dll.

3. Managemen Puncak

Manajemen puncak atau top level management merupakan tingkat manajemen paling atas dan juga mempunyai otoritas yang paling tinggi pada suatu organisasi perusahaan serta memiliki tanggung jawab langsung kepada pemilik perusahaan. Pada umumnya, manajemen puncak ini hanya bekerja pada suatu tatanan konseptual dan juga pemikiran, bukan pada berbagai hal teknis. Manajemen puncak ini mempunyai wewenang paling besar diantara tingkatan manajemen lainnya.

Tingkat manajemen puncak memiliki hal penuh untuk mengangkat, memilih, serta memberhentikan manajemen lain yang berada dibawahnya. Beberapa contoh sebutan tingkat manajemen puncak adalah GM (General Manager), CEO (Chief Executive Officer) dan Presedir atau Presiden Direksi.Direksi adalah suatu perwakilan dari pemilik perusahaan atau pemegang saham, direksi akan dipilih oleh pemegang saham perusahaan, dan CEO biasanya akan dipilih langsung oleh dewan direksi perusahaan.

\section{B. Tingkat Pengambilan Keputusan}

Menurut davis dan Cosenza (1993: 56) dalam pembuatan keputusan dapat diklasifikasi menjadi : keputusan strategis, keputusan taktis dan keputusan teknis. Tingkat keputusan strategis merupakan penentu arah tindakan organisasi dimasa mendatang. Bentuk dari keputusan strategis sangat berorientasi pada masa depan organisasi. Salah satu bentuk keputusan strategis misalnya menentukan produk, menentukan lokasi perusahaan dan menentukan diferensiasi produk. Sedangkan keputusan taktis berorientasi pada sesuatu yang dapat dioperasikan dalam jangka waktu singkat. Keputusan yang dibutuhkan disini adalah keputusan taktis. Misalnya pembelian fasilitasfasilitas bahan ajar. Selanjutnya adalah keputusan teknis, keputusan teknis adalah sebuah keputusan rutinitas yang dilakukan sehari-hari didalam organisasi misalnya seperti menentukan jadwal akademik disebuah perguruan tinggi yang dilakukan oleh bagian akademik. 
Ability : Journal of Education and Social Analysis

Volume 2, Issue 3, Juli 2021

Page : 65-69

C. Jenis-Jenis Pengambilan Keputusan

1. Pengambilan Keputusan Terperogram (Program Decision)

Keputusan yang Diprogram atau Program Keputusan adalah keputusan yang dibuat pada kondisi atau hal-hal yang rutin dan sering terjadi menggunakan prosedur operasi standar atau biasanya dikenal sebagai SOP (Prosedur Operasi Standar).

Program decision cukup efektif dalam menangani masalah sehari-hari di organisasi seperti permintaan cuti karyawan, permintaan pembelian peralatan kantor, dan permintaan lembur karyawan. Setelah keputusan dibuat, program menentukan proses atau prosedur yang harus diikuti ketika situasi yang sama berulang. Aturan, prosedur, dan kebijakan yang dibuat untuk menangani masalah rutin biasanya ditetapkan sebagai Standar Perusahaan.

2. Pengmbilan Keputusan Tidak Terperogram (Non-Programed Decision)

Keputusan yang Tidak Diprogram atau Tidak Diprogram adalah keputusan yang diambil atas masalah yang unik dan belum pernah terjadi sebelumnya. Keputusan Non-Program tidak terstruktur dan tidak memiliki prosedur standar seperti dalam Program Keputusan.

3. Individu dalam pengambilan keputusan kelompok

Pengambilan keputusan kelompok bertujuan agar solusi yang diambil dapat lebih optimal dijalankan. Menurut stoner (1961) keputusan yang diambil kelompok akan lebih ekstrem daripada keputusan yang diambil secara individu, hal ini karena adanya kelompok tentu akan mengakomodasi individu yang berbeda-beda.

\section{Keputusan-Keputusan Perseorangan dan Organisasi}

Keputusan perseoraangan diambil oleh pihak berwenang sesuai dengan jawabannya diorganisasi. Ketika sebuah keputusan diambil oleh seorang berwenang, maka akan berlaku bagi organisasi dan menjadi pijakan dalam tindakan-tindakan.

Keputusan organisasi merupakan respon terhadap keadaan internal dan eksternal. Secara sederhana bahwa keputusan organisasi diambil agar organisasi dapat beradaptasi dengan perubahan, sehingga memiliki cara baru untuk menghadapinya. Tidak hanya factor organisasi yang menentukan sebuah keputusan. Factor pribadi sangat berpengaruh karena pengaalaman seorang manager bisa menjadi penguat bagi keputusan.

\section{E. Partisipasi dalam pengambilan keputusanKesimpulan}

Tingkatan managemen memiliki tiga tingkatan yangi tingkatan lini pertama, tingkatan menengah dan tingkatan puncak. 
Ability : Journal of Education and Social Analysis

Volume 2, Issue 3, Juli 2021

Page : 65-69

Tingkat keputusan strategis merupakan penentu arah tindakan organisasi dimasa mendatang. Bentuk dari keputusan strategis sangat berorientasi pada masa depan organisasi. Salah satu bentuk keputusan strategis misalnya menentukan produk, menentukan lokasi perusahaan dan menentukan diferensiasi produk.

Sedangkan partisipasi dalam pengambilan keputusan yang dimaksud adalah pengambilan keputusan yang dilakukan oleh anggota yang tergabung dalam kelompok yang disebut dengan pengmbilang keputusaan kelompok. Dalam menetapkan dan meningkatkan mutu, apakah keputusan yang diambil secara individual atau oleh partisipasi kelompok yang lebih efektif dan memuaskan orang-orang yang terlibat dalam suatu lembaga.

\section{KESIMPULAN}

Keputusan strategis merupakan penentu arah tindakan organisasi dimasa mendatang. Bentuk dari keputusan strategis sangat berorientasi pada masa depan organisasi. Salah satu bentuk keputusan strategis misalnya menentukan produk, menentukan lokasi perusahaan dan menentukan diferensiasi produk. Sedangkan partisipasi dalam pengambilan keputusan yang dimaksud adalah pengambilan keputusan yang dilakukan oleh anggota yang tergabung dalam kelompok yang disebut dengan pengmbilang keputusaan kelompok. Dalam menetapkan dan meningkatkan mutu, apakah keputusan yang diambil secara individual atau oleh partisipasi kelompok yang lebih efektif dan memuaskan orang-orang yang terlibat dalam suatu lembaga.

\section{DAFTAR PUSTAKA}

Rifa'I, Pengambilan Keputusan.Jakarta : Kencana.2020

https:// bukunnq.wordpress.com/makalah-pengambilan-keputusan-secara-

objektif-dan-konstruktif/

Kasim, Azhar. Teori Pembuatan Keputusan. Jakarta : Lembaga Penerbit FE UI. 1995

Syamsi, Ibnu. Pengambilan Keputusan (Decision Making). Jakarta : Bina Aksara. 1989

http:/ / detik.com diakses Kamis, 04 Oktober 2012

http:/ / hendriansdiamond.blogspot.com/2012/01/choice-menurut-terry1989-faktor-faktor.html

http:/ / tondielia.blogspot.com/2012/10/teori-organisasi-umum-1.html 